https://doi.org/10.30910/turkjans.515361

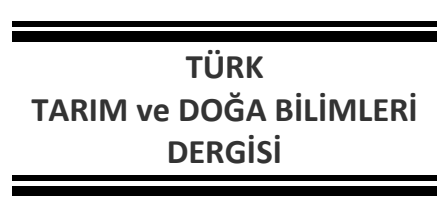

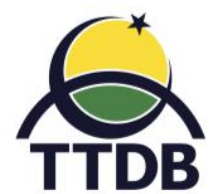

www.dergipark.gov.tr/turkjans

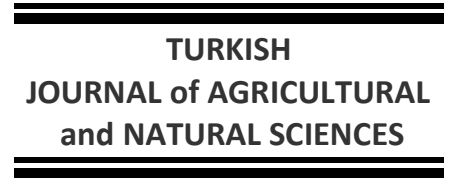

Research Article

\title{
Combined Salt and Nickel Stress Impact on ROS Generation and Antioxidant Enzymes Activities of Lemon Balm (Melissa officinalis)
}

\author{
Hülya TORUN
}

Faculty of Agriculture and Natural Science, Düzce University, 81620 Düzce, Turkey

Corresponding author: hulyatorun@duzce.edu.tr

Received: 28.11.2018

Received in Revised: 26.12 .2018

Accepted: 14.01.2019

\begin{abstract}
Plants acclimation to stress is a complex process and this complexity increase with simultaneous subjection to two or more abiotic stress. Salinity and excess accumulation of nickel are growth and development restricted abiotic stress agents. The aim of the present study was to determine the antioxidant defense system responses of Melissa officinalis (lemon balm) to salinity, nickel and their combinations. Growth, leaf osmotic potential, chlorophyll fluorescence, relative water content (RWC), lipid peroxidation, $\mathrm{H}_{2} \mathrm{O}_{2}$ and proline content and antioxidant enzyme activities were determined under these stress conditions. Growth and leaf osmotic potential negatively affected due to the combined effect of salt and nickel. All three stress treatments did not show any significant change on RWC and chlorophyll fluorescence in lemon balm. $\mathrm{H}_{2} \mathrm{O}_{2}$ content and lipid peroxidation of combined stress had greater than salt and nickel alone. Total activities of ascorbate peroxidase (APX) and glutathione reductase (GR) were increased with salt, nickel and their combinations. Moreover, the reduction in superoxide dismutase (SOD), peroxidase (POX) and catalase (CAT) activities resulted in higher lipid peroxidation and $\mathrm{H}_{2} \mathrm{O}_{2}$ content under the combined stress. To the best of our knowledge, this is the first study conducted on the activities of antioxidant defense enzymes of lemon balm under salinity and nickel combinations.
\end{abstract}

Key words: Abiotic stress combination, antioxidant enzyme, lemon balm, Melissa officinalis, nickel, salinity.

\section{Kombine Tuz ve Nikel Stresinin Limon Otu (Melissa officinalis)'nun ROS Üretimi ve Antioksidan Enzim Aktiviteleri Üzerine Etkisi}

\begin{abstract}
Özet
Bitkilerin strese alışması karmaşık bir süreçtir ve bu karmaşıklık iki veya daha fazla abiyotik strese aynı anda maruz kalındığında artar. Tuzluluk ve aşırı nikel birikimi büyüme ve gelişimi sınırlandıran abiyotik ajanlardır. Bu çalışmanın amacı, Melissa officinalis (limon otu) bitkisinde tuzluluk, nikel ve bunların kombinasyonlarına karşı antioksidan savunma sistem cevaplarını belirlemektir. Bu stres koşulları altında, büyüme, yaprak ozmotik potansiyeli, klorofil floresansı, nisbi su içeriği (RWC), lipid peroksidasyonu, $\mathrm{H}_{2} \mathrm{O}_{2}$ ve prolin içeriği ve antioksidan savunma enzimleri belirlenmiştir. Büyüme ve yaprak osmotik potansiyeli tuz ve nikel kombinasyonları nedeniyle olumsuz etkilenmiştir. Her üç stres uygulaması, limon otunun RWC ve klorofil floresansında önemli değişiklik göstermemiştir. Birleşik stres altındaki $\mathrm{H}_{2} \mathrm{O}_{2}$ içeriği ve lipid peroksidasyonu, tuz ve nikelin tekli uygulamalarından daha yüksektir. Askorbat peroksidaz (APX) ve glutatyon redüktaz (GR)'ın toplam aktiviteleri tuz, nikel ve kombinasyonları ile artmıştır. Dahası, süperoksit dismutaz (SOD), peroksidaz (POX) ve katalaz (CAT) aktivitelerindeki düşüş, birleşik stres altında yüksek lipid peroksidasyonu ve $\mathrm{H}_{2} \mathrm{O}_{2}$ içeriğinin artması ile sonuçlanmıştır. Bildiğimiz en iyi şekilde, bu çalışma tuzluluk ve nikel stresleri kombinasyonları altında limon otunun antioksidan savunma enzim aktivitelerinin yürütüldüğü ilk çalışmadır.
\end{abstract}

Anahtar kelimeler: Abiyotik stres kombinasyonu, antioksidan enzim, limon otu, Melissa officinalis, nikel, tuzluluk. 


\section{Introduction}

Abiotic stresses cause detrimental effects on plant growth, development and yield. In the field conditions, the combined effects of the two or more different abiotic stresses is complicated when compared to the response of stresses applied individually (Mittler 2006). Salt and heavy metal stresses are one of the most encountered stresses in the field conditions. Although responses to salinity and heavy metals have been separately studied in many times, there is still little information about the impact of the combination of these two stress factors. However, according to the Stress Matrix, an unknown interaction was reported between salinity and nickel (Zandalinas et al., 2018).

$\mathrm{Ni}$ is a heavy metal which strongly phytotoxic at high concentrations for plants; however, it is also an essential element in small amounts for growth and development of plants (Kazemi et al., 2010). Excessive nickel causes nickel stress in plants resulting increases lipid peroxidation and hydrogen peroxidase contents (Wang et al., 2009; Sharma and Dhiman, 2013), reduces photosynthesis and respiration (Seregin and Kozhevnikova, 2006) and increases proline content (Singh et al., 2012).

Like other abiotic agents, salinity and heavy metals change the metabolite levels in the cell as enhancing the production of singlet oxygen, superoxide, hydroxyl and hydrogen peroxide $\left(\mathrm{H}_{2} \mathrm{O}_{2}\right)$ known as reactive oxygen species (ROS) (Rizhsky et al., 2002). In order to scavenge overproduction of ROS, enzymatic (ascorbate peroxidase (APX), catalase (CAT), glutathione reductase $(G R)$, peroxidase (POX), superoxide dismutase (SOD)) and nonenzymatic antioxidants (tocopherols, carotenoids, ascorbic acid, glutathione) have been developed by plant cells in different organels such as chloroplast, mitochondria, and peroxisomes (Mittler et al., 2004).

Lemon balm (Melissa officinalis L., Lamiaceae) is an important medicinal plant which was used for gastrointestinal complaints, headache and fever in ancient times (Shakeri et al., 2016; Boneza and Niemeyer, 2018). Most studies with lemon balm were related to its rich source of antioxidants, in particular from the group of phenolic compounds (Capecka et al., 2005; Radácsi et al., 2016; Miraj et al., 2017). The antioxidant response of lemon balm have been studied only under salinity (Ozturk et al., 2004), drought (Radácsi et al., 2016, Rahimi et al., 2016), iron deficiency (Amooaghaie and
Roohollahi, 2017) and nickel stress (Maivan et al., 2017). However, the impact of the combination of salt and nickel stresses on ROS formation and antioxidant defense system in lemon balm have not been still conducted.

Therefore, because of little information about the physiological and biochemical behavior of $M$. officinalis under abiotic stress conditions, this plant was selected as an important aromatic and medicinal plant for this study. To examine the tolerance potential of lemon balm when subjected to combination of salt and nickel based on changes in the values of relative plant growth (RGR), relative water content (RWC), osmotic potential, chlorophyll fluorescence (Fv/Fm), proline level, oxidative stress markers such as lipid peroxidation (TBARS) and hydrogen peroxide $\left(\mathrm{H}_{2} \mathrm{O}_{2}\right)$ content and antioxidant enzyme activities were aimed in the present study.

\section{Material and Methods \\ Plant material and stress applications}

Lemon balm (Melissa officinalis L., Lamiaceae) seeds were used in this study. The seeds were sterilized with ethanol (70\%), rinsed in deionised water and then treated with commercial bleach (5\%). The seeds were washed again with deionized water for removing the bleach. After that, seeds were germinated $\left(22^{\circ} \mathrm{C}, 70 \%\right.$ humidity in the dark). Uniformly germinated seeds were selected and cultivated in organic media made of peat moss, perlite and sand (1:1:1). The seedlings were grown in a controlled plant greenhouse for 30 days: $27 / 22^{\circ} \mathrm{C}$ day/night and $70 \%$ relative humidity. Finally, the pots were separated as Control, Salt (NaCl; $100 \mathrm{mM})$, Nickel $\left(\mathrm{NiSO}_{4} .7 \mathrm{H}_{2} \mathrm{O} ; 500 \mu \mathrm{M}\right)$ and Salt+Nickel (Fig. 1). Five different concentrations of nickel $(50,100$, 250,500 and $1000 \mu \mathrm{M}$ ) solutions were used to determine the appropriate concentration for plants. $500 \mu \mathrm{M}$ was chosen that induces plant growth and physiological responses, but does not kill lemon balm plants. Mature leaves were harvested after two weeks. Harvested leaves frozen with liquid nitrogen and immediately stored at $-80^{\circ} \mathrm{C}$ for analyses.

\section{Relative growth rate (RGR)}

In the beginning and after two weeks of stress treatment, six plants in each group were selected used for the growth analyses. To determine dry weights (DW) of the samples, they were dried in an oven $\left(70^{\circ} \mathrm{C}\right.$ for $\left.72 \mathrm{~h}\right)$. The 
RGR of leaves was calculated according to (Hunt et al. 2002).

$$
R G R=\left(\ln \left(D W_{2}\right)-\ln \left(D W_{1}\right)\right) /\left(t_{2}-t_{1}\right)
$$

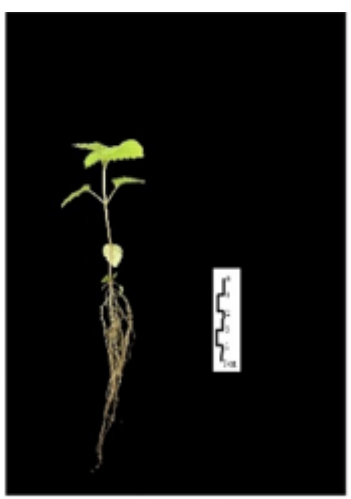

Control

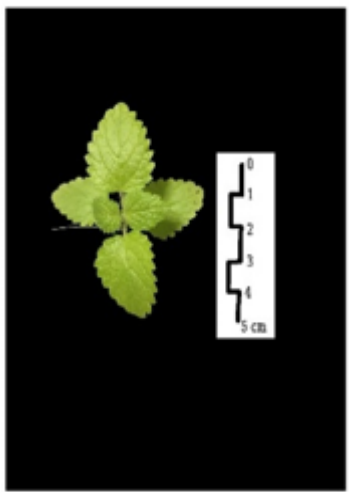

Control

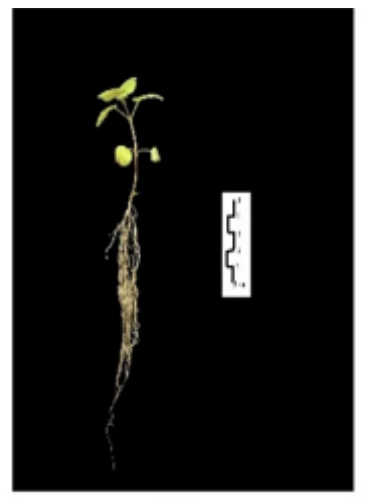

Salt

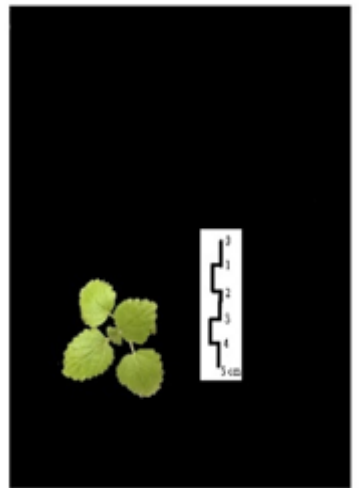

Salt

$\mathrm{DW}_{1}$; dry weight $(\mathrm{g})$ at time $1, \mathrm{DW}_{2}$; dry weight $(\mathrm{g})$ at time 2 ; and $\mathrm{t}_{1}$ and $\mathrm{t}_{2}$; initial harvest time 1 and final harvest time 2 in days.

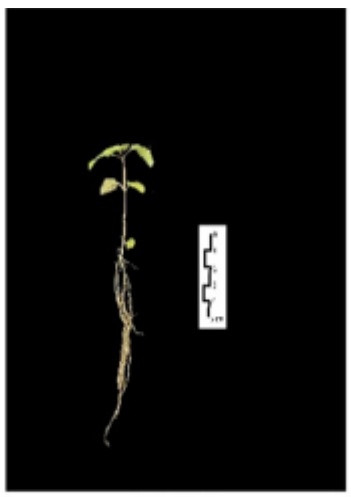

Nickel

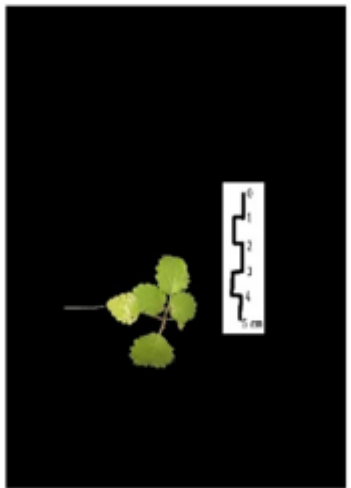

Nickel

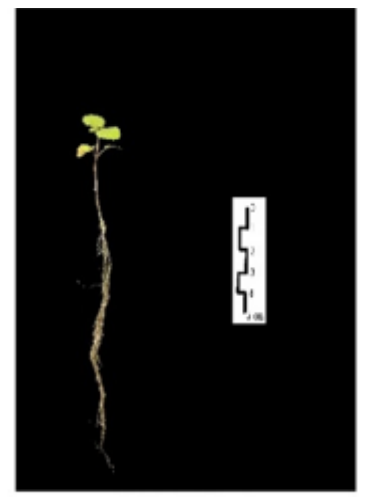

Salt+Nickel

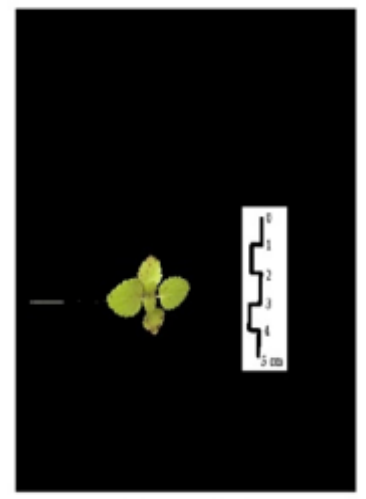

Salt+Nickel

Figure 1. Morphological effects of salt, nickel and their combinations on grown of Melissa officinalis L. Scale bar, $5 \mathrm{~cm}$.

\section{Relative water content (RWC)}

After harvest, leaves from each group weighed and described as fresh weight (FW). After that, leaves were put in water at least $8 \mathrm{~h}$ and then turgid weight (TW) was determined. Turgid leaves were then dried in an oven and dry weight (DW) was determined. RWC was calculated by using the following formula: RWC $(\%)=((F W-D W) /(T W-D W)) \times 100$

\section{Chlorophyll fluorescence (Fv/Fm)}

Before harvest, Fv/Fm were measured in ten dark adapted leaves of lemon balm by Plant Efficiency Analyzer of Hansatech, UK.

\section{Leaf osmotic potential $\left(\boldsymbol{\Psi}_{s}\right)$}

After harvest, osmometer (Wescor Vapro Pressure Osmometer 5600) was used to measure $\psi_{\mathrm{s}}$ of leaves. These results obtained from the instrument converted to MPa (SantaCruz et al., 2002).

\section{Lipid peroxidation}

Thiobarbituric acid reactive substances (TBARS) were used to determine lipid peroxidation levels and detected by using the method of (Heath and Packer 1968).

\section{$\mathrm{H}_{2} \mathrm{O}_{2}$ quantification}

The method described by Liu et al (2000) was used to measure the accumulation of $\mathrm{H}_{2} \mathrm{O}_{2}$ (using $\mathrm{TiCl}_{4}$ method) and the results expressed as $\mu \mathrm{mol} \mathrm{g} \mathrm{g}^{-1} \mathrm{FW}$.

\section{Proline quantification}

The method described by Bates et al (1973) was used to determine the free proline content (using the acid-ninhydrin method) and the results were expressed as $\mu \mathrm{mol}$ proline $\mathrm{g}^{-1}$ FW.

\section{Antioxidant enzyme extractions and assays}

For antioxidant enzyme extractions, leaf samples $(0.5 \mathrm{~g})$ were immediately ground with 
liquid nitrogen and ice-cold phosphate buffer (50 mM; pH 7.0; 1 mM EDTA and 1\% polyvinylpyrrolidone (PVP)) were used for homogenization. Ascorbate $(2 \mathrm{mM})$ was added to the phosphate buffer for determining APX activity assay. The protein content in the extract was detected with bovine serum albumin (BSA; standard) (Bradford, 1976). The SOD (EC.1.15.1.1), POX (EC.1.11.1.7), CAT (EC 1.11.1.6), APX (EC 1.11.1.11) and GR (1.6.4.2) activities in extract were measured according to the methods described by Beauchamp and Fridovich (1971), Mika and Lüthje (2003), Aebi (1984), Nakano and Asada (1981) and Foyer and Halliwell (1976), respectively. While one unit of SOD activity was defined as the quantity of enzyme needed to produce $50 \%$ inhibition of NBT, one unit of POX, CAT, APX and GR activities were defined as $1 \mu \mathrm{mol}$ of product formed per $\min ^{-1}$.

\section{Statistical analysis}

Data were evaluated using ANOVA and Duncan's Multiple Range Test were utilized between groups to compare significant differences at $\mathrm{P}<0.05$. Replicates in each experiment were determined as two biological and three technical.

\section{Results and Discussion \\ Relative water content (RWC) and relative growth rate ( $R G R$ )}

Reduction in water content and growth are the first responses of abiotic stress conditions. RWC of salt and salt+nickel-treated lemon balm leaves was not affected by these conditions when compared to the control plants, while nickel increased the RWC by $11.6 \%$ (Fig. 2A). The $M$. officinalis leaves maintained their water content may be in order to protect the roots and shoots of the plant. Similar results in plants which resumed water content of their leaves were detected under abiotic stress conditions (Turkan et al., 2005; Sekmen et al., 2014). However, RGR decreased by 30.4, 21.7 and $78.3 \%$ with salt, nickel and salt+nickel, respectively, when compared to control plants (Fig. 2B). As similar results reported in the literature, salinity reduced growth rate (Parida and Das, 2005). This decrease in growth may be due to osmotic, ionic imbalances or huge accumulation of ROS resulting from excess ions or nutritional deficiency (Greenway and Munns, 1980). This result also consistent with lemon balm grown under nickel stresses, that fresh and dry weight of shoots was reported to reduce (Maivan et al., 2017).

\section{Chlorophyll fluorescence (Fv/Fm) and leaf osmotic potential $\left(\Psi_{s}\right)$ \\ $\mathrm{Fv} / \mathrm{Fm}$ is a quantum efficiency of} photosystem II and it was measured under salt, nickel and their combinations in lemon balm. Flanagan and Jefferiers (1988) reported that the $\mathrm{Fv} / \mathrm{Fm}$ was reduced by drought and salt as a stress conditions. In our study, salt alone caused a reduction $(1.7 \%)$ in chlorophyll fluorescence of lemon balm as compared to control plants (Fig. 2C). However, like in RWC, Fv/Fm was increased by $1.5 \%$ with the application of nickel alone. There were no significant changes on Fv/Fm under the combination of salt and nickel as compared to control plants. Similarly to saltstressed barley (Seckin et al., 2010), unchanged Fv/Fm content under stress conditions means of well-protected leaf photochemistry in lemon balm. Moreover, increase in Fv/Fm content may be related to nickel. This result suggests that nickel may have an important role in photosynthetic apparatus. However, contrary to our results chlorophyll a and carotenoid content decreased in lemon balm under nickel stress (Maivan et al., 2017). On the other hand, salt alone decreased leaf osmotic potential (56.9\%), while there was no significant effect of nickel alone (Fig. 2D). Moreover, the combined salt and nickel significantly reduced $\Psi_{\mathrm{s}}$ by $66.6 \%$ as compared to control plants. Plants modify water uptake and loss to cope with low water potential by accumulating water soluble compound (Verslues et al., 2006). Lemon balm may accumulate more water soluble compounds under the combined salt and nickel stress. These results suggest that the detrimental effect of combined salt and nickel on growth and leaf osmotic potential was greater than that of salt and nickel stresses alone.

\section{TBARS, $\mathrm{H}_{2} \mathrm{O}_{2}$ and proline content}

Lipid peroxidation is broadly used for monitoring oxidative damage in plant cells and TBARS were measured to determine the lipid peroxidation level under salt and nickel stresses. The TBARS levels of only salt and nickel-treated plants increased by $44.5 \%$ and $7.8 \%$, respectively, when compared to control group, but it was more pronounced (53\%) in the combination of salt and nickel-treated lemon balm plants (Fig. 3A). Salinity reduced growth rate and osmotic potential while increasing 
TBARS and proline levels in the leaves (Parida and Das, 2005). $\mathrm{H}_{2} \mathrm{O}_{2}$, as a ROS, is one of the most important redox molecule and involves in several signaling cascades in plants (Neill et al., 2002). In our experiments, $\mathrm{H}_{2} \mathrm{O}_{2}$ content was increased by salt and nickel alone $50 \%$ and $19.2 \%$, respectively, as compared to control plants (Fig. 3B). Moreover, the combination of salt and nickel also increased the $\mathrm{H}_{2} \mathrm{O}_{2}$ content (38.5\%). Similarly to our findings, lemon balm plants showed higher $\mathrm{H}_{2} \mathrm{O}_{2}$ accumulation under Ni stress (Maivan et al., 2017). Proline is one of the most compatible osmolyte accumulating under stress conditions. In this study, the proline content of salt+nickel-treated plants did not show any significant change, while salt alone enhanced it by $71.8 \%$ and nickel alone $61.8 \%$, as compared to control (Fig. 3C). Opposite to our result, Maivan et al (2017) reported unchanging proline accumulation under nickel stress in lemon balm. The proline content was reduced with the combination of salt and nickel, but leaf osmotic potential was also decreased. This result suggests that another compatible osmolyte in the cell may be accumulated to protect leaf water content.
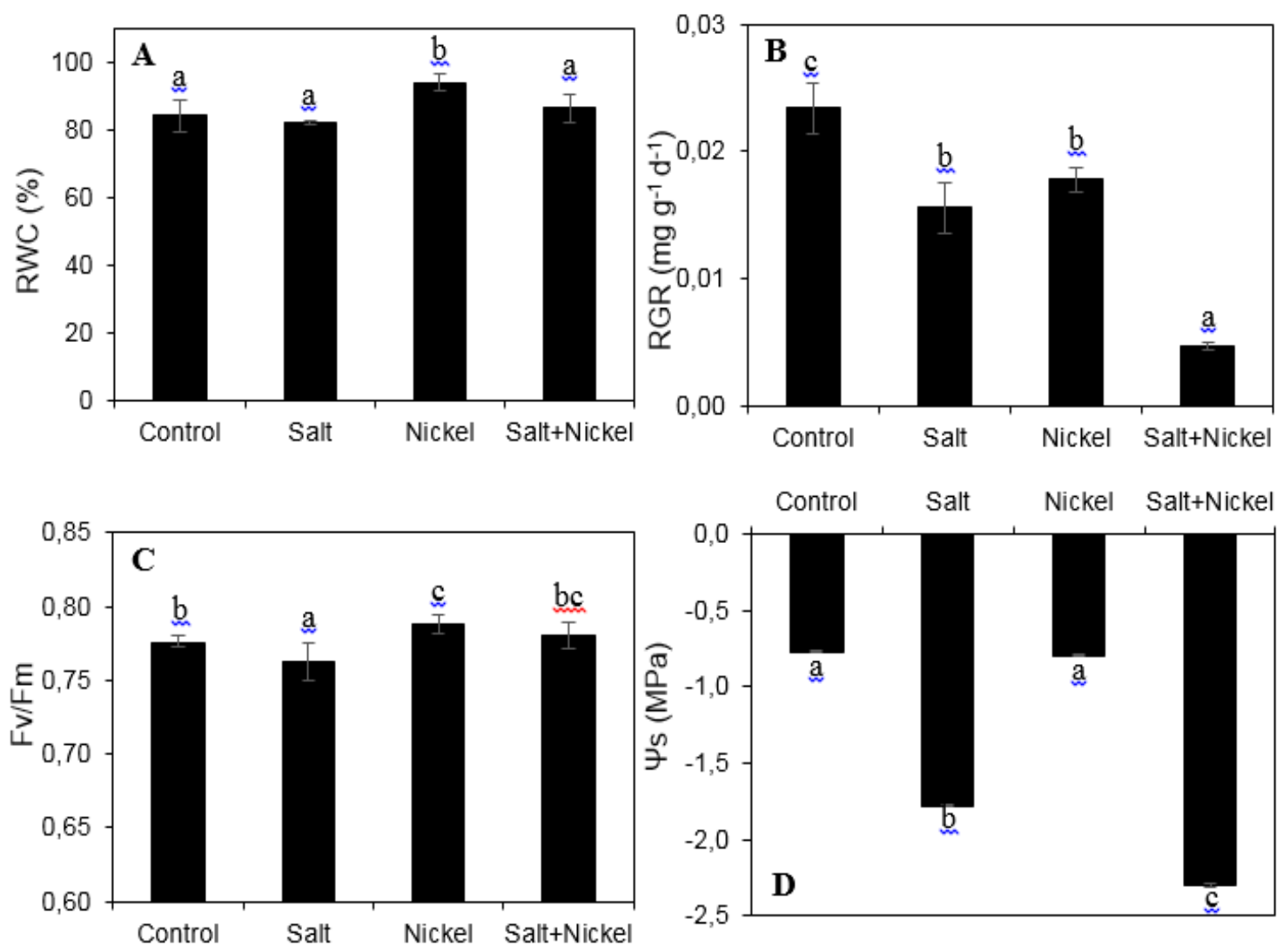

Figure 2. Relative water content (RWC; A), relative growth rate (RGR; B), chlorophyll fluorescence (Fv/Fm; C) and leaf osmotic potential ( $\Psi_{\mathrm{S}}$; D) of Melissa officinalis L. grown under control, salt, nickel and the combination of salt and nickel. Data are means $\pm \mathrm{SE}$; Values followed by the same letter are not significantly different according to Duncan's test $(P<0.05)$.

\section{Antioxidant enzyme activities}

Increase in ROS production involved in the stress response signal transduction pathway during salt stress threaten cells (Mittler, 2002). ROS-scavenging antioxidant defense system enzymes (APX, CAT, GR, POX and SOD) activities are important to cope with this threat. Moreover, high antioxidant enzyme activities caused better ROS scavenging capacity in plant genotypes. In the literature, there is little information about antioxidant defense system of lemon balm plants under different stress types and moreover none of them are related to combined effects of stress types. The SOD converts $\mathrm{O}_{2} \cdot-$ to more stable $\mathrm{H}_{2} \mathrm{O}_{2}$ and its activity is an significant for cellular defense against oxidative stress (Mittler et al., 2004) In this study, salt and salt+nickel treatments significantly decreased the SOD activity of lemon balm leaves by 21.6 and $9.9 \%$, respectively, 
while no significant change was detected in nickel-treated plants (Fig. 4A). POX, CAT and APX are the main scavengers of $\mathrm{H}_{2} \mathrm{O}_{2}$ in plants (Mittler et al. 2004). POX activity of M. officinalis was not significantly induced by all three stress treatments (Fig. 4B). CAT activity was observed the lowest activity among all antioxidant enzymes measured in this study (Fig. 4C). Moreover, CAT activity of salt-treated plants was decreased $2.7 \%$ as compared to control group, while no significant changes were determined in nickel and the combination of nickel and salt plants. On the other hand, significant increase was observed in the APX activity of all treated groups used in this study. The enhancements were 50, 75 and $58.3 \%$ in salt, nickel and their combination stresses, respectively, when compared to control group (Fig. 4D). GR is an Asada-Halliwell-Foyer cycle

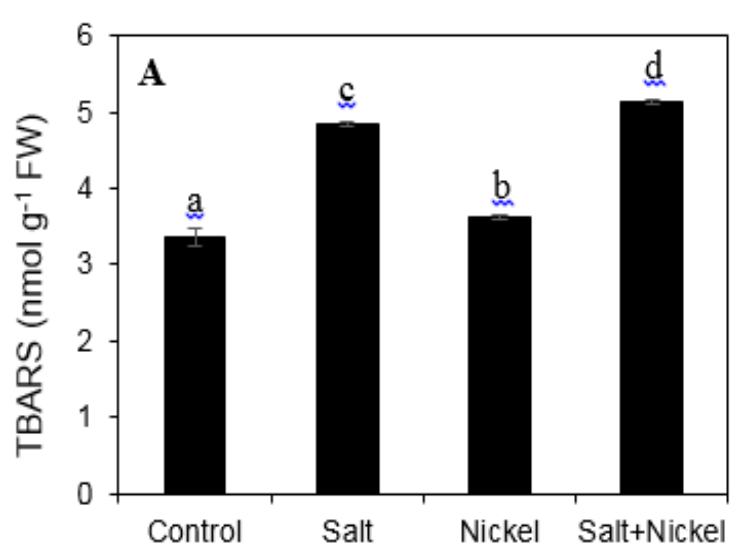

enzyme, and uses NADPH as reducing power to reduce the oxidized glutathione (GSSG) and ensures glutathione pool reduced in the plant cell (Foyer and Noctor, 2011). Salt, nickel and the combination of salt and nickel significantly increased the GR activity in lemon balm leaves (Fig. 4E). However, salt stress displayed a robust increase (7-fold) in the activity. The rate of increment was the same in nickel and salt+nickel-treated plants (75\%). Taken together, salt stress significantly reduced SOD and CAT activities, while increased APX and GR activities in lemon balm leaves. Moreover, APX and GR activities also increased under the combination of salt and nickel stresses. These results suggest that decreases in SOD and CAT activities might not help to overcome the cellular damage by reducing the TBARS and the $\mathrm{H}_{2} \mathrm{O}_{2}$ content.

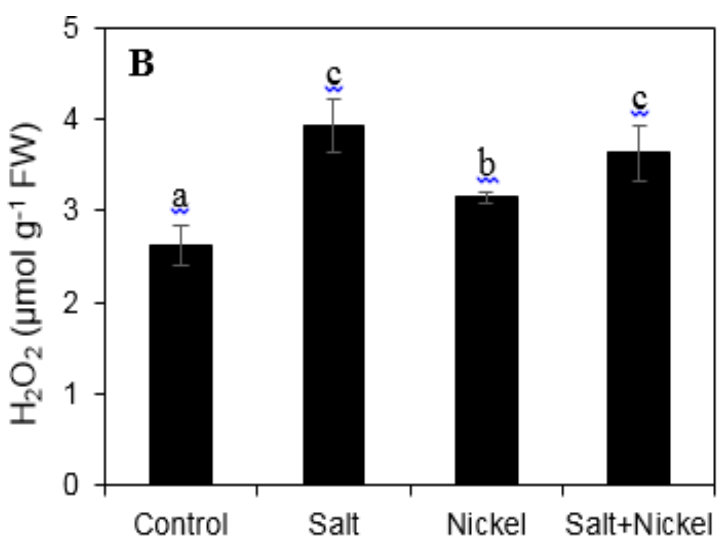

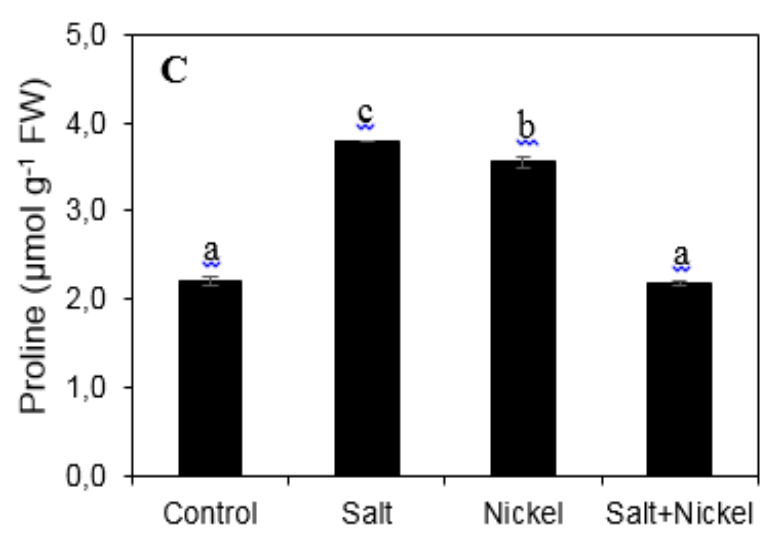

Figure 3. TBARS (A), $\mathrm{H}_{2} \mathrm{O}_{2}$ (B) and proline content (C) of Melissa officinalis L. grown under control, salt, nickel and the combination of salt and nickel. Data are means $\pm \mathrm{SE}$; Values followed by the same letter are not significantly different according to Duncan's test $(P<0.05)$.

\section{Conclusion}

Plant growth and water content were significantly reduced by salt and nickel stress applications. Stress-induced damage was related to the reduction in RGR and water potential and increases in TBARS and $\mathrm{H}_{2} \mathrm{O}_{2}$ content. When salt and nickel applied with together, the harmful effects increased. The antioxidant defense enzyme activities especially CAT, POX and SOD were suppressed under the 
combination of salt and nickel. These results suggest that the detrimental effect of combined salt and nickel stresses on physiological and biochemical compositions in lemon balm was greater than that of salt and nickel stress alone. Moreover, plants increased the APX and GR
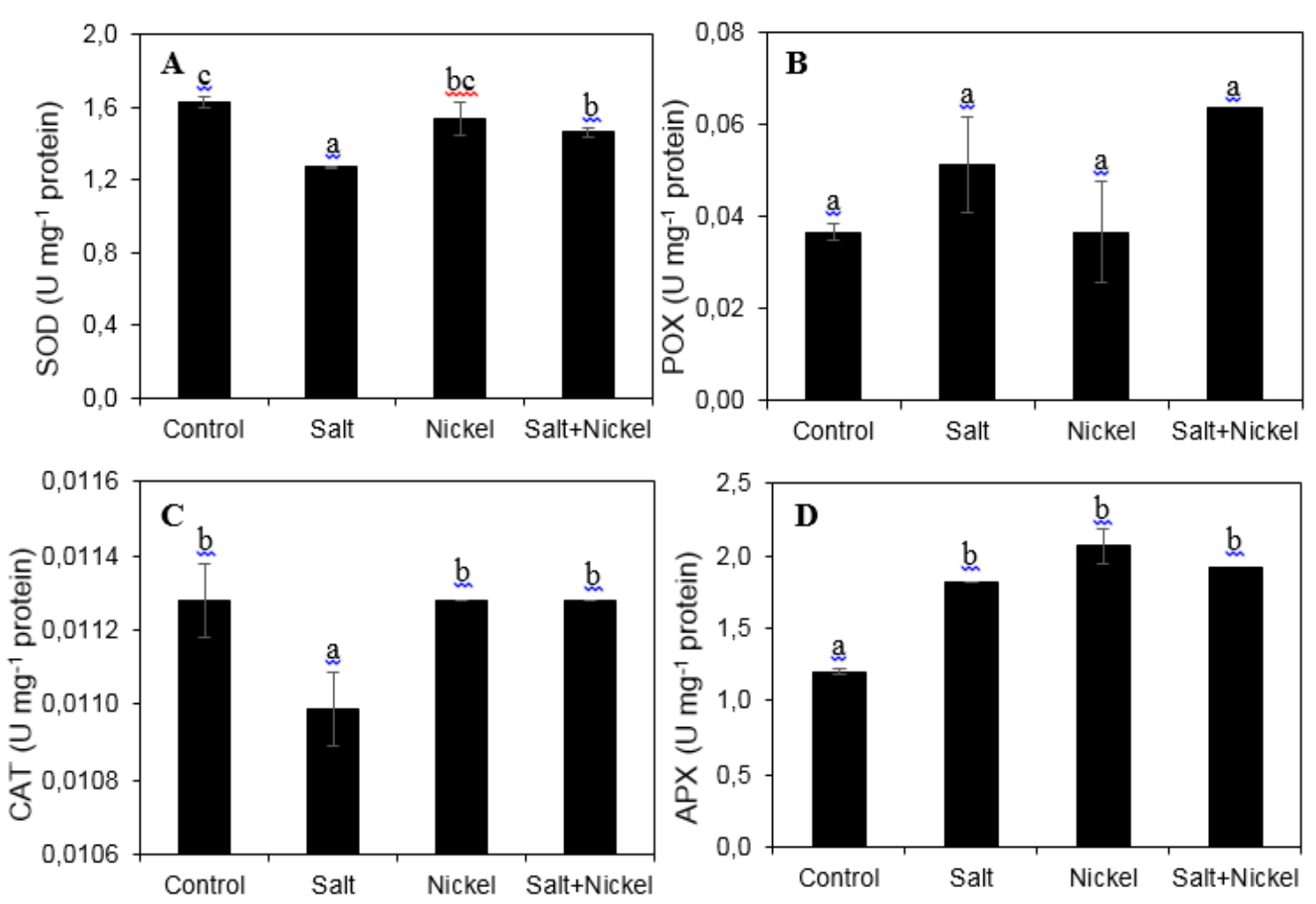

activities to struggle with stress conditions, therefore RWC was maintained under the combined stress. In summary, the combination of salt and nickel had negative effects in terms of improving the antioxidative system in $M$. officinalis.

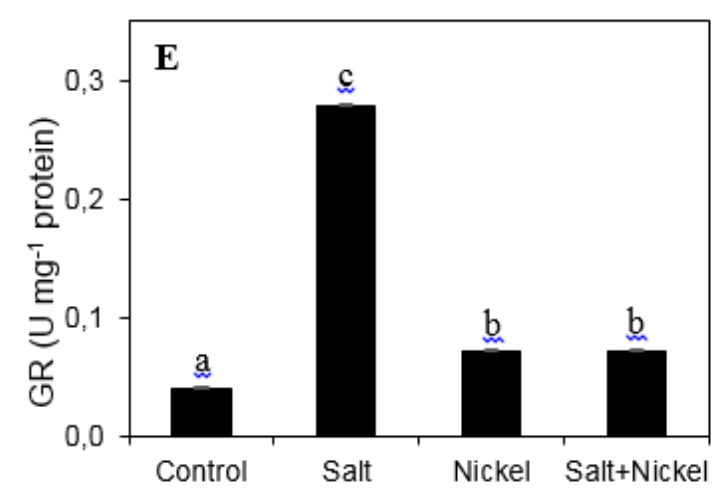

Figure 4. SOD (A), POX (B), CAT (C), APX (D) and GR (E) activities of Melissa officinalis L. grown under control, salt, nickel and the combination of salt and nickel. Data are means $\pm \mathrm{SE}$; Values followed by the same letter are not significantly different according to Duncan's test $(P<0.05)$.

\section{References}

Aebi, H. 1984. Catalase In Vitro. In: Methods in Enzymology. (eds) Colowick, S.P., Kaplan, N.O., Orlando: Academic Press, pp.114121.

Amooaghaie, R., Roohollahi, S.H. 2017. Effect of sodium nitroprusside on responses of Melissa officinalis to bicarbonate exposure and direct Fe deficiency stress. Photosynthetica, 55(1): 153-163.

Bates, L.S., Waldren, R.P., Teare, I.D. 1973. Rapid determination of free proline for water stress studies. Plant Soil, 39: 205-207.

Beauchamp, C., Fridovich, I. 1971. Superoxide dismutase: improved assays and an assay 
applicable to acrylamide gels. Analytical Biochemistry, 44: 276-287.

Boneza, M.M., Niemeyer, E.D. 2018. Cultivar affects the phenolic composition and antioxidant properties of commercially available lemon balm (Melissa officinalis L.) varieties. Industrial Crops and Products, 112: 783-789.

Bradford, M.M. 1976. A rapid and sensitive method for the quantization of microgram quantities of protein utilizing the principle of the protein-dye binding. Analytical Biochemistry, 72: 248-254.

Capecka, E., Mareczek, A., Leja, M. 2005. Antioxidant activity of fresh and dry herbs of some Lamiaceae species. Food Chemistry, 93: 223-226.

Flanagan, L.B., Jefferiers, R.L. 1988. Stomatal limitation of photosynthesis and reduced growth of the halophyte Plantago maritima L. at high salinity. Plant, Cell \& Environment, 11: 239-245.

Foyer, C.H., Halliwell, B. 1976. The presence of glutathione and glutathione reductase in chloroplasts: A proposed role in ascorbic acid metabolism. Planta, 133: 21-25.

Foyer, C.H., Noctor, G. 2011. Ascorbate and glutathione: the heart of the redox hub. Plant Physiology, 155: 2-18.

Heath, R. L., Packer, L. 1968. Photoperoxidation in isolated chloroplasts, I. kinetics and stoichiometry of fatty acid peroxidation. Archives in Biochemistry and Biophysics, 125: 189-198.

Hunt, R., Causton, D.R., Shipley, B., Askew, A.P. 2002. A modern tool for classical plant growth analysis. Annals of Botany, 90: 485-488.

Greenway, H., Munns, R. 1980. Mechanisms of salt tolerance in nonhalophytes. Annual Review of Plant Biology, 31: 149-190.

Kazemi, N., Khavari-Nejad, R.A., Fahimi, H., Saadatmand, S., Nejad-Sattari, T. 2010. Effects of exogenous salicylic acid and nitric oxide on lipid peroxidation and antioxidant enzyme activities in leaves of Brassica napus L. under nickel stress. Scientia Horticulturae, 126: 402-407.

Liu, J., Lu, B., Xun, A.L. 2000. An improved method for the determination of hydrogen peroxide in leaves. Progress in Biochemistry and Biophysics, 27: 548551.

Maivan, E.S., Radjabian, T., Abrishamchi, P., Talei, D. 2017. Physiological and biochemical responses of Melissa officinalis L. to nickel stress and the protective role of salicylic acid. Archives of Agronomy and Soil Science, 63(3): 330343.

Mika, A., Lüthje, S. 2003. Properties of guaiacol peroxidase activities isolated from corn root plasma membranes. Plant Physiology, 132: 1489-1498.

Miraj, S., Rafieian-Kopaei, M., Kiani, S. 2017. Melissa officinalis L: A review study with an antioxidant prospective. Journal of Evidence-Based Complementary \& Alternative Medicine, 22(3): 385-394.

Mittler, M. 2002. Oxidative stress, antioxidants and stress tolerance. Trends in Plant Science, 7: 405-410.

Mittler, R., Vanderauwera, S., Gollery, M., Van Breusegem, F. 2004. The reactive oxygen gene network in plants. Trends in Plant Science, 9: 490-498.

Mittler, R. 2006. Abiotic stress, the field environment and stress combination. Trends in Plant Science, 11: 15-19.

Nakano, Y., Asada, K. 1981. Hydrogen peroxide is scavenged by ascorbate specific peroxidase in spinach chloroplasts. Plant and Cell Physiology, 22: 867-880.

Neill, S.J., Desikan, R., Clarke, A., Hurst, R., Hancock, J. 2002. Hydrogen peroxide and nitric oxide as signalling molecules in plants. Journal of Experimental Botany, 53: 1237-1247.

Ozturk, A., Unlukara, A., Ipek, A., Gurbuz, B. 2004. Effects of salt stress and water deficit on plant growth and essential oil content of lemon balm (Melissa officinalis L.). Pakistan Journal of Botany, 36(4): 787-792.

Parida, A.K., Das, A.B. 2005. Salt tolerance and salinity effects on plants: A review. Ecotoxicology and Environmental Safety, 60: 324-349.

Radácsi, P., Szabó, K., Szabó, D., Trócsányi, E., Németh-Zámbori, E. 2016. Effect of water deficit on yield and quality of lemon balm (Melissa officinalis L.). Zemdirbyste-Agriculture, 103(4): 385390.

Rahimi, M., Kordrostami, M., Maleki, M., ModaresKia, M. 2016. Investigating the effect of drought stress on expression of $W R K Y 1$ and EREBP1 genes and antioxidant enzyme activities in lemon 
balm (Melissa officinalis L.). 3 Biotech, 6(1): 99

Rizhsky, L., Hallak-Herr, E., Van Breusegem, F., Rachmilevitch, S., Barr, J.E., Rodermel, S., Inze, D., Mittler, R. 2002. Double antisense plants lacking ascorbate peroxidase and catalase are less sensitive to oxidative stress than single antisense plants lacking ascorbate peroxidase and catalase. Plant Journal, 32: 329-342.

Santa-Cruz, A., Martinez-Rodriguez, M.M., Perez-Alfocea, F., Romero-Aranda, R., Bolarin, M.C. 2002. The rootstock effect on the tomato salinity response depends on the shoot genotype, Plant Science, 162: 825-831.

Seckin, B., Turkan, I., Sekmen, A.H., Ozfidan, C. 2010. The role of antioxidant defense systems at differential salt tolerance of Hordeum marinum Huds. (sea barleygrass) and Hordeum vulgare L. (cultivated barley). Environmental and Experimental Botany, 69: 76-85.

Sekmen, A.H., Ozgur, R., Uzilday, B., Turkan, I. 2014. Reactive oxygen species scavenging capacities of cotton (Gossypium hirsutum) cultivars under combined drought and heat induced oxidative stress. Environmental and Experimental Botany, 99: 141-149.

Seregin, I.V., Kozhevnikova, A.D. 2006. Physiological role of nickel and its toxic effects on higher plants. Russian Journal of Plant Physiology, 53(2): 257-277.

Shakeri, A., Sahebkar, A., Javadi, B., 2016. Melissa officinalis L. -A review of its traditional uses: phytochemistry and pharmacology. Journal of Ethnopharmacology, 188: 204-228.

Sharma, A., Dhiman, A. 2013. Nickel and cadmium toxicity in plants. Journal of Pharmaceutical and Scientific Innovation, 2: 20-24.

Singh, G., Agnihotri, R.K., Reshma, R.S. Ahmad, M. 2012. Effect of lead and nickel toxicity on chlorophyll and proline content of Urd (Vigna mungo L.) seedlings. International Journal of Plant Physiology and Biochemistry, 4(6): 136-141.

Turkan, I., Bor, M., Ozdemir, F., Koca, H. 2005. Differential responses of lipid peroxidation and antioxidants in the leaves of drought-tolerant $P$. acutifolius Gray and drought-sensitive $P$. vulgaris $L$. subjected to polyethylene glycol mediated water stress. Plant Science, 168: 223-231.

Verslues, P.E., Agarwal, M., Katiyar-Agarwal, S., Zhu, J., Zhu, J.-K. 2006. Methods and concepts in quantifying resistance to drought, salt and freezing, abiotic stresses that effect plant water status. The Plant Journal, 45: 523-539.

Wang, H., Feng, T., Peng, X., Yan, M., Tang, X., 2009. Up-regulation of chloroplastic antioxidant capacity is involved in alleviation of nickel toxicity of Zea mays L. by exogenous salicylic acid. Ecotoxicology and Environmental Safety, 72(5): 1354-1362.

Zandalinas, S.I., Mittler, R., Balfagón, D., Arbona, V., Gómez-Cadenas, A. 2018. Plant adaptations to the combination of drought and high temperatures. Physiologia Plantarum, 162: 2-12. 